ИСТОРИЈСКИ ЧАСОПИС, књ. LXVII (2018) стр. 55-82

THE HISTORICAL REVIEW, vol. LXVII (2018) pp. 55-82

УДК: 94(497.5)(497.1):327(450.341),,12/14“

\title{
Ивана КОМАТИНА*
}

Историјски институт

Београд

\section{Предраг КОМАТИНА*}

Византолошки институт САНУ

Београд

\section{НАСТАНАК „МЛЕТАЧКЕ АЛБАНИЈЕ“ И УСПОМЕНА НА ВИЗАНТИЈСКУ ВЛАСТ У СРПСКОМ ПОМОРЈУ**}

\begin{abstract}
Ancmpaкm: У раду се истражују историјске и политичке околности које су као резултат имале настанак „Млетачке Албаније“. Такође, посебна пажња је посвећена проматрању односа између Албаније у географском, политичком и историјском погледу и новоосноване „Млетачке Албаније“, тј. проналази се историјска нит која је Млечанима била упориште за коришћење назива Албанија на простору српског Поморја од Скадра до Котора.

Кључне речи: „Млетачка Албанија“, Албанија, Драч, Зета, Горња Далмација, српско Поморје.
\end{abstract}

„Млетачка Албанија“ (Albania Veneta) је била историјско-географска целина која је настала након млетачког преузимања Драча од његовог албанског господара Ђорђа Топије 1392. године и опстала све до мира у Кампоформију и прикључења Венеције и преосталих млетачких поседа на Јадрану Аустрији 1797. године. Иако је њен настанак био везан за

\footnotetext{
*ivana.komatina@iib.ac.rs

*predrag.komatina@visanu.ac.rs

** Рад је настао као резултат истраживања на пројектима Министарства просвете, науке и технолошког развоја Републике Србије: Средњовековне српске земье (13-15. век): политички, привредни, дручтввени и правни прочеси (ев. бр. 177029) и Традииија, иноваиија и идентитет у византијском свету (ев. бр. 177032).
} 
млетачко заузимање Драча, њена територија се превасходно, а након пада Драча под Османлије 1501. године и искључиво, простирала на подручју средњовековног српског Поморја, од Скадра до Котора, које пре ширења „Млетачке Албаније“ никада није било сматрано ни називано „Албанијом“. ${ }^{1}$ Пошто је у питању била комплексна творевина, која је била обликована од различитих целина - Драча, Албаније у ужем смислу и јужнојадранских градова који су раније припадали српској држави, неопходно је осврнути се на историјски развој сваке од њих и објаснити њихов међусобни однос, како у ранијим вековима, тако и у време стварања „Млетачке Албаније“.

\section{Генеза појма „Албанија“ - Од Арбанског кнежевства до Краљевине Албаније}

Најпре треба објаснити географски, историјски и политички однос између историјске Албаније и новоосноване „Млетачке Албаније“. Први трагови политичке организације Албанаца (Арбанаса) допиру у средину XII века, када је област Арбана - шире подручје око града Кроје у залеђу Драча, била део Драчког дуката Византијског царства. ${ }^{2}$ После пада Цариграда у руке крсташа уследиле су велике геополитичке промене које нису заобишле ни југозападни Балкан. Тако у уговору познатом под називом Partitio Romaniae којим је предвиђен начин поделе Византијског царства између Млечана и крсташа, „провинција Драч и Арбан са хартуларатима Главинице, Вагенитије” између осталог припадају Млечанима. Дакле, Драч и Арбан су са нижим јединицама чинили једну провинцију тј. тему која је према уговору требало да у целости припадне Млечанима. ${ }^{3}$ Међутим, Драч, није одмах доспео у руке Млечана већ су га заузели после кратке борбе 1205. год. Недуго потом отпочеле су борбе са

1 О распростирању назива „Албанија“ у периоду XII-XIV век, уп. О. J. Schmitt, Das venezianische Albanien (1392-1479), München 2001, 49-52.

2 У кратком периоду седамдесетих година XII века област Арбана прикључена је новој административној творевини, дукату Дукље, Далмације, Хрватске, Арбаније и Сплита. На челу тог дуката се налазио севаст Константин Дука. Међутим, након смрти цара Манојла I Комнина Угри су заузели Хрватску и Далмацију, а Срби приморске градове, те се област Арбана вратила у састав Драчког дуката, П. Коматина, „А од Арбанаса Пилот “: Почеци политичке историје Албанаца, Стефан Немања - Преподобни Симеон Мироточиви, Зборник радова, БеоградБеране 2016, 135-141.

3 П. Коматина, Област Вагенитија и епископија Св. Климента, ЗРВИ 53 (2016) 85-86. 
епирским деспотом Михаилом Анђелом око преосталих поседа а уговор између две стране је потписан 1210. године, којим су Драч и област Арбана, ипак, остали у млетачким рукама. ${ }^{4}$

Управо из тог периода потичу и први писани подаци о политичкој организацији Албанаца на простору око Кроје. Димитрије, син Прогона, помиње се у документима као panyperseuastos et magnus archon, Arbanensis princeps, judex Albanorum, што говори о постојању Principatus Arbanensis (Арбанског кнежевства), чији се владар снажно опирао успостављању млетачке врховне власти. ${ }^{5}$ Међутим, Михаило Епирски је после 1213. проширио своју власт на Арбан и чак је напао српски Скадар, о чему Стефан Првовенчани пише у Житију Св. Симеона, али и успео да освоји Драч, који је остао у епирским рукама пуних седамнаест година. ${ }^{6}$

Након битке код Клокотнице 1230. године Арбан („Арбанашка земља“") и Драч су дошли под врховну власт Бугара, ${ }^{7}$ да би се потом поново нашли у епирским рукама, а око тог простора отпочели су ратови и са Никејским царством. Цару Јовану III Ватацу се најпре потчинио албански кнез, а затим и епирски владар. ${ }^{8}$ Међутим, убрзо долази до

${ }^{4}$ Према уговору из 1210. склопљеном између Епираца и Млечана „дукат Никопољ са пертиненцијама Арте, Ахелоја и Анатолије и Лесијане; и осталих архонтија и манастира; провинција Јањина; Грандис; провинција Вагенитија; провинција Дринопољ и остало; провинција Колонија; и хартуларат Главиница" припали су Епирцима, док је подручје северно од тога остало Млечанима. Осим тога, Михаило Епирски је постао вазал Млечана, И. Божић, Албанија и Арбанаси у XIII, $X I V$ и XV веку, Глас САНУ 338, Одељење историјских наука, књ. 3 (1983) 22-24; П. Коматина, Област Вагенитија, 86-87.

5 A. Ducellier, La façade maritime de l'Albanie au moyen age. Durazzo et Valona du XI ${ }^{e}$ au XV siècle, Thessaloniki 1981, 138-149; П. Коматина, Почеци политичке историје Албанаиа, 138-139.

${ }^{6}$ Стефан Првовенчани, Сабрана дела, изд. Љ. Јухас-Георгиевска, Т. Јовановић, Београд 1999, 88-92; И. Коматина, Историјска подлога чуда Св. Симеона у Житију Симеоновом од Стефана Првовенчаног, ЗРВИ 51 (2014) 126-127; A. Ducellier, Façade maritime, 149-151, 160-166.

7 Уп. повељу Јована Асена II Дубровчанима из 1230, Д. Живојиновић, Хоризма бугарског иара Јована Асена II Дубровнику, Иницијал 1 (2013) 233, и трновски натпис истог цара из истог времена, Г. Томовић, Морфологија ћириличких натписа на Балкану, Београд 1974, 38; П. Коматина, Почеци политичке историје Албанаиа, 139-140.

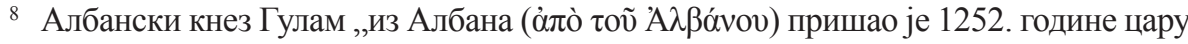

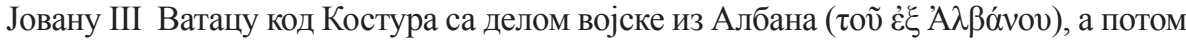
се исте године и епирски владар потчинио никејском цару. Михаило II Епирски

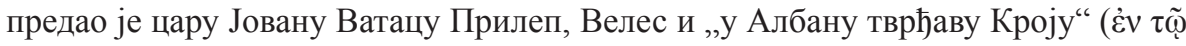


нових ратова између Епираца и Никејаца око тих поседа који свој епилог добијају у великој бици код Пелагоније 1259. у којој су Никејци предвођеним Михаилом Палеологом однели одлучујућу победу. ${ }^{9}$

У тим догађајима учешће је узео и сицилијански краљ Манфред из дома Хоенштауфен. Током 1258. године он је заузео Драч, Валону, Канину, Берат, Сфинарицу, Сопот, Бутринт и Крф. Епирски владар Михаило II склопио је са њим савез против Никејаца и признао му освојене територије. ${ }^{10}$ Насупрот томе, Арбанаси из драчког залеђа остали су, макар номинално, поданици никејског цара. ${ }^{11}$ Међутим, након Манфредове погибије краљ Сицилије постао је Карло Анжујски (1266-1285) који је са тим положајем наследио и претензије на све Манфредове територије на супротној обали Јонског мора, које је у међувремену поново заузео деспот Михаило II. ${ }^{12}$

У жељи да поново освоји некадашње Манфредове поседе на Балкану, Карло је склопио споразум са бившим латинским царем Балдуином II Куртнејским, уз посредовање папе у Витербу 1267. године, којим је Карло требало да помогне бившем цару да поврати своје царство, а заузврат је Балдуин признао Карлу, између осталог, право на ,сву земљу коју је деспот Михаило дао својој кћерци Јелени, удовици покојног Манфреда.“ Осим тога, доделио му је и „трећи део целог царства које треба да се поново

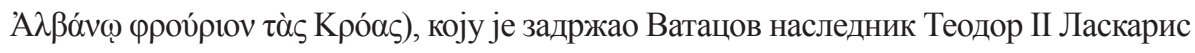
(1254-1258). Током 1256. године Теодору II Ласкарису се потчинио читав Албан (

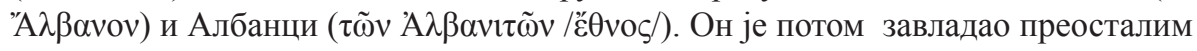
поседима епирског деспота, а међу њима и Драчем, Georgii Acropolitae Opera, I, edd. A. Heisenberg, P. Wirth, Stutgardiae 1978, 91-92, 139-140; И. Божић, Албанија и Арбанаси, 26.

9 Г. Острогорски, Историја Византије, Београд 1959, 419-420; A. Ducellier, Façade maritime, 166-176; И. Божић, Албанија и Арбанаси, 26-27.

${ }^{10}$ Том приликом је договорен брак између Манфреда и Михаилове кћери Јелене, те су те територије биле део мираза, Г. Острогорски, Историја, 419-420; A. Ducellier, Façade maritime, 173-176; И. Божић, Албанија и Арбанаси, 27. Acropolites, I, 157-158; Nicephori Gregorae Byzantina Historia I, ed. L. Schopen, Bonnae 1829 (CSHB), 71-72, помињу брак и уговор, али не и територије. Марин Санудо, С. Hopf, Chroniques Gréco-romanes, Berlin 1873, 107, наводи Драч, Валону и Крф. Један акт из Драча од 23. феб. 1258. датује се првом годином владавине Манфреда „У граду Драчу, Берату, Валони, гори Сфинарици и поседима и провинцијама тих земаља“", Acta et diplomata res Albaniae mediae aetatis illustrantia I, edd. L. Thalloczy, K. Jireček, E. Sufflay, Vindobonae 1913, no. 246.

${ }^{11}$ A. Ducellier, Façade maritime, 178-180.

${ }^{12}$ Г. Острогорски, Историја, 426-428; И. Божић, Албанија и Арбанаси, 28. 
освоји, у земљи поменутог деспота и у краљевствима Албанији и Србији“ (in terra memorati despoti ac in regnis Albaniae et Serviae). ${ }^{13}$ Управо та одредба уговора у Ветербу представља прво помињање „Краљевине Албаније“regnum Albaniae.

Права прилика за освајања на Балкану Карлу се указала 1271, услед смрти деспота Михаила II. Почетком 1272. Карло је на свом двору примио „посланике и амбасадоре многих кнежева и барона Албаније који су му изнели жељу својих сународника да га признају за свог господара“. ${ }^{14}$ Након тога Карло је послао своје људе „да преузму Краљевину Албанију и њено господство и владавину са свим правима и принадлежностима од прелата, кнежева и племића и заједница и појединаца речене краљевине и да прихвате избор који су поменути учинили њега и његових наследника за краљеве реченог краљевства и да преузму посед тог краљевства и заклетву верности““. ${ }^{15}$ Фебруара 1272. Карло прихвата потчињавање Драча и његових становника, узима их под своју заштиту и потврђује им „све древне привилегије царева Романије и њихове добре обичаје и слободе“, а затим исте привилегије потврђује и „прелатима, кнежевима, баронима, витезовима, грађанима, заједницама и појединцима Албаније, који су њега и његове наследнике изабрали за краљеве и сталне господаре поменутог краљевства“" и обећава да ће их штитити „као добри господар своје вазале“. ${ }^{16}$ Повељом коју је издао 25. фебруара 1272, а у којој се титулише као „Карло, милошћу Божјом краљ Сицилије и Албаније“, именовао је свог капетана и општег намесника (capitaneus et vicarius generalis) у Краљевини Албанији. ${ }^{17}$

Дакле, сицилијански краљ Карло I Анжујски је на простору некадашњег Арбанског кнежевства успоставио „Краљевину Албанију“ као посебну политичку целину под својом влашћу. Међутим, она у почетку није обухватала град Драч, већ само територију насељену Албанцима у његовом залеђу. ${ }^{18}$ Ипак, већ у периоду $1272-1275$. краљ чини прве кораке

\footnotetext{
${ }^{13}$ Acta Albaniae I, no. 253.

${ }^{14}$ Посланство су чинили севасти Павле Брака, Петар Лети и Петар Миси, Acta Albaniae I, no. 266; A. Ducellier, Façade maritime, 232-240.

${ }^{15}$ Acta Albaniae I, no. 266.

${ }^{16}$ Ibidem, no. 268-269.

${ }^{17}$ Ibidem, no. 270 sq.

${ }^{18}$ У првим анжујским актима који се тичу тог простора о Драчу се увек говори засебно у односу на Албанију: „у пределима земаља наших Драча и Албаније“ (in partibus terrarum nostrarum Durachii et Albaniae), „наш град и земља Драч“ („,castrum nostrum et terra Durachii“), Драчка земља (terra Durachii)..., Acta Albaniae I, no. 272, 278.
} 
ка успостављању заједничке администрације у двема територијама, мада се Драчка земља и даље наводи као посебна у односу на Албанију. ${ }^{19}$ Као господар Манфредовог наслеђа, Карло је владао и градовима у данашњој јужној Албанији - Канином, Валоном, Бератом. ${ }^{20}$ Премда је администрација у њима повремено била такође потчињена капетану и намеснику Драча и Албаније, они нису сматрани за део Албаније, већ „Романије“. ${ }^{21}$ Анжујска Краљевина Албанија је потрајала, међутим, тек нешто више од једне деценије. Након вишегодишњег рата први цареви из дома Палеолога успели су да до 1284. поврате и Албанију и Драч у оквир свог Царства. ${ }^{22}$ Међутим, ни византијска власт није дуго потрајала, пошто су се и Драч и његово албанско залеђе већ 1296. нашли под влашћу српског краља Стефана Уроша II. ${ }^{23}$

За то време анжујске претензије на Албанију нису биле заборављене, већ је, напротив, пажљиво припремано њихово оживљавање. Наиме,

${ }^{19}$ Он најпре 1272. овлашћује свог капетана и општег намесника Краљевине Албаније и маршала Краљевине Албаније да имају надлежност над пословима у граду Драчу, 1274. поставља Петра де Естина за кастелана града Драча и потчињава га Нарзу де Тусију, кога надаље ословљава као „капетана и намесника Драча“, да би 1275. поставио Виљема Бернарда за „капетана нашег краљевства Албаније и Драча“, Acta Albaniae I, no. 283, 285, 290-292, 298, 309-311, 317, 327 , 330, 343, 357, 359-360, 394-395, 401, 410-411, 416, 434, 450, 454-455, 458, 482; A. Ducellier, Façade maritime, 240-262.

${ }^{20}$ Acta Albaniae I, no. 319; A. Ducellier, Façade maritime, 232-262. Поменути градови су се налазили у изворном подручју историјско-географске области Вагенитије, П. Коматина, Област Вагенитија, 83-100.

${ }^{21}$ О томе сведочи један акт из 1279. године у коме краљ Карло тадашњег капетана Хуга де Сулијака ословљава као „капетана и намесника у пределима Албаније, Драча, Валоне, Бутринта, Сопота и Крфа, Acta Albaniae I, no. 394, да би потом именовао посебног „капетана Драча и Албаније“, а поменутог Хуга надаље ословљавао као „капетана у пределима Романије“ (capitaneus noster in partibus Romaniae), Acta Albaniae I, no. 394 sq, 428-429, 431-432, 438.

${ }^{22}$ Г. Острогорски, Историја, 434-435; A. Ducellier, Façade maritime, 253-262; И. Божић, Албанија и Арбанаси, 31-32. Цар Андроник II је 1288. године албанској престоници граду Кроји и њеним становницима потврдио привилегије својих претходника Јована III Ватаца и Теодора II Ласкариса, Acta Albaniae I, no. 508. Његова повеља је сачувана само у латинском преводу, у оквиру касније повеље граду Кроји арагонског и сицилијанског краља Алфонса V из 1457. године, L. Thallóczy, C. Jireček, Zwei Urkunden aus Nordalbanien, Archiv für slavische Philologie 21 (1899) 97-98.

${ }^{23}$ Г. Острогорски, Историја, 456; A. Ducellier, Façade maritime, 323-329; И. Божић, Албанија и Арбанаси, 32. 
1294. године тадашњи сицилијански краљ Карло II доделио је свом сину Филипу, кнезу Тарента, сва своја права на поседе на Балканском полуострву - „Кнежевину Ахају, Атинско војводство, Краљевину Албанију, провинцију Влахију (Тесалију) и остале пределе Царства Романије, на копну и острвима“. ${ }^{24}$ Тако је Филип, као кнез Тарента, постао титулар свих анжујских права и претензија на територије источно од Јонског мора и главни носилац анжујске политике на Балканском полуострву.

Ипак, саму Албанију са Драчем Филип је стекао тек десет година касније, почетком септембра 1304. године, када су Драчани и Албанци збацили српску и поново признали анжујску власт. Тада је он издао низ привилегија „Драчанима који су се повратили у верност“, „сталежима Краљевине Албаније“, албанским племенима и појединим великашима, ${ }^{25}$ чиме је некадашња Краљевина Албанија била обновљена у пуном обиму. На њеном челу је био он као кнез Тарента и „господар Краљевине Албаније“, док је непосредну власт над Драчем и албанским племенима у унутрашњости, фактички самосталним, вршио његов „капетан Драча““ ${ }^{26}$ Град Драч, иако се третирао као посебна целина, ипак је, за разлику од првог периода анжујске владавине, у потпуности припадао Краљевини Албанији. ${ }^{27}$

${ }^{24}$ То се догодило приликом склапања брака између Филипа и Тамаре, кћери епирског владара деспота Нићифора I, после чије смрти је понео и титулу „деспота Романије“, Acta Albaniae I, no. 523; Г. Острогорски, Историја, 455; А. Ducellier, Façade maritime, 326-327; И. Божић, Албанија и Арбанаси, 32.

${ }^{25}$ Acta Albaniae I, no. 561-569; Г. Острогорски, Историја, 462; A. Ducellier, Façade maritime, 329-330; И. Божић, Албанија и Арбанаси, 33.

${ }^{26}$ Acta Albaniae I, no. 580, 584, 597-598, 626, 688; Anonymi descriptio Europae Orientalis, прир. Т. Живковић, В. Петровић, А. Узелац, Београд 2013, 116-117: „део овог краљевства, заједно са поменутим градом Драчем, сада држи тарентски кнез, син сицилијанског краља, и то по слободној вољи господара те земље који су њега... добровољно прихватили за господара... Поменуто краљевство Албаније сада нема ниједног краља, али земља је подељена између кнежева који њом управљају и који никоме нису подређени“; Itinerarium Symon Semeonis ab Hyberniam ad Terram Sanctam, ed. M. Esposito, Dublin 1960, 38: „град Драч... сада припада кнезу Романије, брату поменутог јерусалимског краља, и налази се у провинцији Албанији“; A. Ducellier, Façade maritime, 329-338; И. Божић, Албанија и Арбанаси, 39;

27 ... principalis thesaurarii in civitate Dyrachii et regno Albaniae..., ... de archiepiscopatu Duraseno in regno Albaniae..., Acta Albaniae I, no. 607, 633. То истичу и савремени наративни извори, попут Анонимног описа Источне Европе из 1308. и ирског путописца Симона Фицсимонса, који је боравио у Драчу 1322. године, Anonymi descriptio Europae Orientalis, 116: „У Албанији... ипак, имају један град 
После смрти Филипа Тарентског, децембра 1332. године је дошло, међутим, до значајних промена у политичком статусу Драча и Албаније. Филипови наследници склопили су тада уговор са његовим братом Јованом, којим су сва своја права на Филипово наслеђе у „поменутима Краљевини Албанији и граду Драчу“ (,in predictis regno Albaniae at civitate Duracii““) предали Јовану и његовим потомцима, у замену за његову Кнежевину Ахају и извесну новчану надокнаду. ${ }^{28}$ Том приликом је град Драч издвојен из оквира Краљевине Албаније и у њему је успостављено посебно „Драчко војводство“, са Јованом на челу. ${ }^{29}$ Од тог тренутка се у документима анжујске канцеларије увек говори о „Краљевини Албанији и Драчком војводству“ у множини (in predictis regno Albaniae et ducatu Dyrachii). ${ }^{30}$ Као некада владавина сицилијанских краљева и тарентског кнеза, тако је и сада владавина драчких војвода над Краљевином Албанијом била нестабилна и зависила у највећој мери од степена оданости тамошњих албанских великаша, који су били склони да лако мењају стране и потчињавају се снажнијем господару. ${ }^{31}$ Тако су већ почетком четрдесетих година XIV века били принуђени да признају српску власт. ${ }^{32}$ Тиме су Анжујци трајно изгубили албанску територију у драчком залеђу, чијим је падом под српску власт и анжујска Краљевина Албанија фактички престала да постоји. ${ }^{33}$ Међутим, ни Драчко војводство није још

који се зове Драч и који припада Латинима и из њега, наиме, добијају одећу и све потрепштине“; Itinerarium Symon Semeonis, 38: „град Драч... сада припада кнезу Романије, брату поменутог јерусалимског краља, и налази се у провинцији Албанији“.

${ }^{28}$ Acta Albaniae I, no. 763; Г. Острогорски, Историja, 473-474; A. Ducellier, Façade maritime, 334-335; И. Божић, Албанија и Арбанаси, 38-39.

${ }^{29}$ Након тога Јован се титулисао као „војвода Драча и Краљевине Албаније“, односно као „војвода Драча и господар Краљевине Албаније“, а исто тако и његов син Карло, који га је наследио 1335. године, Acta Albaniae I, no. 767, 792, 807-808, 816-817.

${ }^{30}$ Acta Albaniae I, no. 787, 792, 805, 807-808, 816-817.

${ }^{31}$ A. Ducellier, Façade maritime, 335-346.

${ }^{32}$ Српски краљ Стефан Душан издао је јуна 1343. нову повељу о потврди старих привилегија граду Кроји и њеним становницима, Acta Albaniae I, no. 834, такође сачувану само у латинском преводу у оквиру повеље Алфонса V из 1457, L. Thallóczy, C. Jireček, Zwei Urkunden, 96-97; A. Ducellier, Façade maritime, 357-359, 470-474.

${ }^{33}$ И сам Драч се можда у неком тренутку накратко нашао у српским рукама, али су 1346. њиме и даље владали Анжујци, Г. Острогорски, Историја, 483; А. Ducellier, Façade maritime, 357-359; И. Божић, Албанија и Арбанаси, 40-41. У анжујским актима из 1346. и 1363. године говори се о „Драчком војводству“ и 
Настанак „,Млетачке Албаније“ и успомена на византијску власт у српском поморју

дуго опстало, јер је Драч 1368. године освојио Карло Топија, ${ }^{34}$ албански великаш који је искористио расуло у Српском царству после смрти цара Стефана Душана и постао независни господар Албанаца око града Кроје. ${ }^{35}$

\section{Настанак Млетачке Албаније}

Успон Карла Топије средином XIV века био је велика прекретница у албанској историји. Након што је постао „господар“, односно „кнез Албаније“ (dominus Albaniae, princeps Albaniae), Карло Топија је освајањем Драча од Анжујаца тај град и његово албанско залеђе поново објединио под владавином једног владара. Он се од тада најчешће називао „кнезом Албаније и господарем Драча“, чиме је и даље јасно истицао разлику између двеју територија - Албаније и Драча. ${ }^{36}$

„граду Драчу“, „капетану града Драча“ и „кастелану града Драча“, „војвоткињи Драча“ и „граду и војводству Драча“, али о „Краљевини Албанији““ у њима више нема помена, Acta et diplomata res Albaniae mediae aetatis illustrantia II, edd. L. Thalloczy, K. Jireček, E. Sufflay, Vindobonae 1918, no. 21, 23-24, 195.

${ }^{34}$ Acta Albaniae II, no. 239; Acta Albaniae Veneta saeculorum XIV et XV, ed. J. Valentini, I/1, Panormi 1967, no. 213; A. Ducellier, Façade maritime, 478-479; И. Божић, Албанија и Арбанаси, 51. Анжујци су још једном покренули акцију са циљем да поврате град и „читаву Краљевину Албанију“, коју је 1372. отпочео драчки војвода Луј од Наваре, који је говорио како жели „да заузме читаву Краљевину Албанију, која му по праву припада због госпође Јованке, војвоткиње Драча, његове жене“, Acta Albaniae II, no. 286, али су успели да га задрже само накратко између 1376. и 1379, јер је поново пао у руке Карла Топије, чиме је дефинитивно окончано столетно присуство Анжујаца на албанској обали, а са њим и идеја о „Краљевини Албанији“, А. Ducellier, Façade maritime, 480-483; И. Божић, Албанија и Арбанаси, 51.

${ }^{35}$ Карло Топија је био припадник истакнуте албанске великашке породице, која је генерацијама имала блиске везе са Анжујцима. Најстарији предак породице, витез Топија (Theopia miles), помиње се у једном уговору између албанских првака и Карла I Анжујског 1274. године, Acta Albaniae I, no. 333. Карловом оцу Танушу су 1338. године драчки војвода и војвоткиња потврдили кнежевину (comitatus) између река Маће и Шкумбе, док је његов стриц фратар Доминик у то време постао капелан и саветник сицилијанског краља Роберта, Acta Albaniae I, no. 802, 816-817. Карлова мајка је наводно била ванбрачна кћерка краља Роберта, због чега се он са

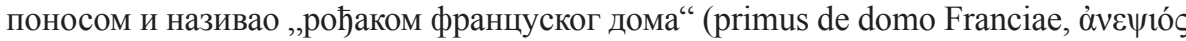

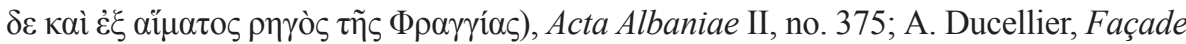
maritime, 474-484, 607, n. 36; И. Божић, Албанија и Арбанаси, 46-48, 50-55.

36 За титуле Карла Топије, уп. Acta Albaniae II, no. 214, 239, 311, 317, 375, 400-402; $A A V \mathrm{I} / 1$, no. 201, 213, 243, $A A V \mathrm{I} / 2$, Mediolani 1968, no. 315-317. 
У то време пак место Анжујаца у албанском приморју преузима једна друга страна сила - Млечани. Након што су одредбама Задарског мира склопљеног са Угарском 1358. године били истиснути из целе Далмације „од Кварнера до граница Драча““, ${ }^{37}$ Млечани су своју пажњу све више усмеравали управо на Драч и његово залеђе. Већ од 1362. Драчани ступају у присније везе са Млечанима, а 1366. године обраћа им се и сам Карло Топија, и том приликом Млечани „племенитом господину Карлу, господару Албаније, у пределима према драчком приморју“ свечано додељују и своје грађанство. ${ }^{38}$

Владавину Карла Топије над Драчем накратко је 1385. године прекинуо српски великаш Балша II Балшић, који је владао територијама и северно и јужно од поседа Топија. Као господар Драча, Балша II је, за разлику од Карла Топије, користио наслов ранијих анжујских владара града - називао се „дуком драчким“. ${ }^{39}$ Након његове погибије у сукобу са Османлијама на Саурском пољу исте године Драч је поново припао Карлу Топији, док су област око Скадра северно од Драча и Химара, Канина, Валона и Берат јужно од њега остали у рукама Балшића. ${ }^{40}$

Услед све веће опасности од Османлија, нарочито после погибије Балше II, Карло Топија се још више повезао са Млечанима и током 1386. и 1387. споразумео са њима да призна њихову врховну власт и своје територије, укључујући и Драч стави под њихову заштиту. ${ }^{41}$ Када је убрзо након тога умро, наследио га је син Ђорђе Топија, који је са титулом „господара Драча“ владао и самим градом и албанском територијом у залеђу, такође под млетачком заштитом, а у драчку тврђаву примио је чак и млетачку војну посаду. ${ }^{42}$ Коначно, када је Ђорђе Топија у јесен 1392. године умро без наследника, град Драч и његово албанско залеђе су припали Млечанима. Они су у Драчу завели своју управу, именовали своје провидуре, капетана и кастелана, и овластили их да

${ }^{37}$ S. Ljubić, Listine o odnošajih izmedju Južnoga Slavenstva i Mletačke republike III, Zagreb 1872, 369; Acta Albaniae II, no. 130; AAV I/1, no. 170-171.

${ }^{38}$ Acta Albaniae II, no. 180, 187, 194, 197, 214, 216, 239; AAV I/1, no. 180, 190-192, 195-196, 201; A. Ducellier, Façade maritime, 475-479.

${ }_{39}$ Acta Albaniae II, no. 388; С. Рудић, Повеља дуке драчког Балие II Дубровчанима, CCA 11 (2012) 101-106.

${ }^{40}$ A. Ducellier, Façade maritime, 490-492; И. Божић, Албанија и Арбанаси, 52.

${ }^{41}$ Acta Albaniae II, no. 400-402, 407-409; AAV I/2, no. 315-317, 325, 329, 332.

${ }_{42}$ Acta Albaniae II, no. 416-417, 419, 422, 424, 431, 436, 438-439, 443, 467, 476, 480-481, 483-484; AAVI/2, no. 350-353, 359-363, 365, 367-368, 371-375, 377-378, 381-382, 390, 409, 416-418, 438-439, 445-446, 448-451; А. Ducellier, Façade maritime, 492-502; И. Божић, Албанија и Арбанаси, 53-56; O. J. Schmitt, Venezianische Albanien, 217-230. 
успоставе млетачко господство и над осталим албанским првацима у залеђу. ${ }^{43}$ Тако су уместо некадашње анжујске „Краљевине Албаније“ 1392. ударени темељи „Млетачкој Албанији“ (Albania Veneta). Акт тадашњег сицилијанског краља Ладислава из јуна 1393. године, којим је наследно право своје тетке Јованке, војвоткиње Драча, на „Драчко војводство и господство Краљевине Албаније“ (ducatum Duracii et dominium regni Albaniae), шест година после њене смрти доделио њеној сестри а својој мајци Маргарети, била је само бледа реакција Анжујаца на велики млетачки успех. ${ }^{44}$

Територија „Млетачаке Албаније“ је убрзо проширена заслугом Ђурђа II Страцимировића Балшића. Наиме, он је владао Зетом након смрти Балше II, али је убрзо дошао у сукоб са Турцима, због чега је пао у ропство и морао да им преда градове Скадар, Дриваст, Св. Срђ и Дањ као услов за своју слободу. ${ }^{45}$ Међутим, 1395. је Скадар и Дриваст отео од Турака, а Дањ од Константина, свог брата од стрица и великог такмаца. Те градове је крајем исте године понудио Млечанима. ${ }^{46}$ Иако је понуда била примамљива, а њеним прихватањем млетачака доминација на јужном делу Јадрана била употпуњена и заокружена, Млечани су били опрезни. Њих није толико оптерећивало што су то заправо били поседи преотети од нове велике силе, Османског царства, колико чињеница да би тим чином можда прекршили одредбе уговора склопљеног 1358. у Задру и 1381. у Торину између њих и Угара. ${ }^{47}$ Наиме, према тим уговорима Млечани су се у корист угарског краља одрекли свих својих права „у круни и краљевини целе Далмације, наиме од средине Кварнера све

43 Acta Albaniae II, no. 486, 488, 491-501; AAV I/2, no. 456-459, 464-466, 468-474, 480-500, 507-529, 531-534, 539-542, 545-557, 559, 563-572, 574, 577, 579, 582583, 586-589; И. Божић, Албанија и Арбанаси, 56-58; О. J. Schmitt, Venezianische Albanien, 230-239. Сам град Кроју у изворној Албанији наследила је Ђорђева сестра Јелена, која се удала за млетачког грађанина Марка Барбадика и заједно са њим владала под млетачком врховном влашћу, Acta Albaniae II, no. 488; AAV $\mathrm{I} / 2$, nо. $459,495,511-515,559,563-565,574$, али су они изгубили град 1394 , када га је заузео Константин Балшић, османски вазал који је њиме владао до своје погибије 1402. године, И. Божић, Dominus rex Constantinus, Немирно Поморје XV века, Београд 1979, 197-205.

44 Acta Albaniae II, no. 502.

${ }^{45}$ Ibidem II, no. 485. $A A V \mathrm{I} / 2$, no. 455.

${ }^{46}$ Acta Albaniae II, no. 544; AAV I/2, no. 601-605; Историја Црне Горе II/2, Титоград 1970, 57-64.

${ }^{47}$ Acta Albaniae II, no. 546-547; AAV I/2, no. 602, 608; S. Ljubić, Listine IV, Zagreb 1874, 353-354. 
до гранища Драча““. ${ }^{48}$ Пошто им није било најјасније да ли се поменуте одредбе односе и на Скадар, Дриваст и Дањ, односно да ли ти градови припадају Далмацији или гранищама Драча, тј. драчкој области, Млечани су јануара 1396. одлучили да наложе драчком капетану да пронађе „све старе повеље које би биле у граду Драчу, како у општини тако и код појединаца, које садрже границе Драча и права и надлежности речене земље“" и помоћу њих утврди историјско-географски опсег драчке области. ${ }^{49}$ То мало историјско истраживање је очигледно релативно брзо завршено, јер су већ у фебруару Млечани послали свог изасланика да се обавести о резултатима „истраге“, а априла 1396. г. и преузели градове Скадар и Дриваст од Ђурђа II без страха од реакције угарског краља. ${ }^{50}$ На питање зашто је она изостала не би се могао дати прецизан одговор. ${ }^{51}$ Ђурађ II је за себе задржао Улцињ и Бар са околином, а од Млечана је за тај велики уступак добио млетачко грађанство за своју породицу, право да се служи заставом Св. Марка, и одређену суму дуката на годишњем нивоу. ${ }^{52}$ На тај начин је „Млетачка Албанија“ добила свој нови обим и раширила се од Скадра до Драча. Ипак, намеће се питање на основу којих докумената су Млечани почетком 1396. доказали своје право да

${ }^{48}, \ldots . .$. renuntiant effectualiter de iure et de facto in manibus supradictorum dominorum episcoporum et actorum dicti domini regis, recipientium nomine et vice dicti domini regis et successorum suorum, in regno et corona toti Dalmatie, a medietate scilicet Quarnarii usque ad confines Duracii, tanquam ab antiquo de iure regno et corone Ungariae spectanti et pertinenti...", S. Ljubić, Listine III, 369; IV, 127, 353-354; Acta Albaniae II, no. 130; AAV I/1, no. 170-171, 271.

${ }^{49}$ Acta Albaniae II, no. 547; AAV I/2, no. 608. Сличну истрагу су Млечани већ били наложили 1393. године, када су желели да утврде да ли град Љеш, који је тада требало да придодају својим поседима, ,јесте или је у старини био унутар граница драчких“, $A A V \mathrm{I} / 2$, nо. 496.

${ }^{50}$ Acta Albaniae II, no. 549, 553, 555-556; AAV I/2, no. 611, 615-617, 620-621, 628, 630-631. Дањ нису успели да заузму, јер га је у међувремену освојио албански великаш Која Закарија, који га је и задржао све до османског освајања 1430. године, ИЦГ II/2, 51, нап. 2, 72, 158; И. Божић, Албанија и Арбанаси, 58-61; О. J. Schmitt, Venezianische Albanien, 237-239, 241-244.

${ }^{51}$ Тешко је рећи да ли је изостанак реакције угарског краља био последица исхода млетачке „истраге“ или неких других политичких околности. Наиме, управо у то време се припремао велики крсташки поход против Османлија у коме су Угарска и Млечани иступали као савезници и који је неславно окончан поразом код Никопоља септембра 1396, Г. Острогорски, Историја, 511. У таквим околностима би Угрима свакако више одговарало да јужнојадрански градови буду у млетачким, а не у турским рукама.

${ }^{52}$ ИЦГ II/2, 63. 
Настанак „Млетачке Албаније“ и успомена на византијску власт у српском поморју

загосподаре Скадром и суседним градовима и како су утврдили да они припадају границама драчке области.

\section{Јужнојадрански градови између Драча и Далмације}

Одмах треба признати да су документи које је млетачки капетан пронашао у Драчу почетком 1396. године били веродостојни - Скадар, Дриваст, Дањ и њихова околина заиста јесу некада припадали Драчу. Међутим, то је било веома давно, још за време византијске власти на том подручју, када се на њему простирала Драчка тема.

Драчка тема је основана у другој деценији IX века, као важно упориште византијске власти на јадранској обали. Обухватала је град Драч и његово залеђе, у коме је живело претежно романско становништво које је у периоду VII-X века развило тзв. културу Комани-Кроја. Том простору припадали су и градови Скадар, Дриваст, Улцињ, Бар. ${ }^{53}$ Средином X века, цар Константин VII Порфирогенит у свом спису De administrando imperio изричито наводи како се српска кнежевина Дукља простирала „до драчких

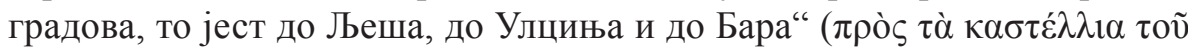

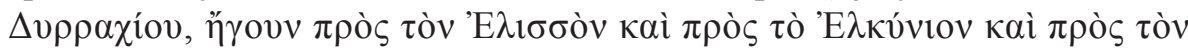

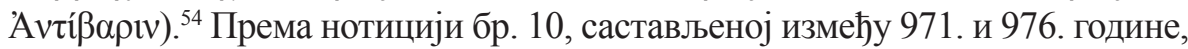
Драчка митрополија Цариградске патријаршије је обухватала и градове Дукљу, Скадар, Дриваст, Пилот, Бар и Градац (Будву). ${ }^{55}$

На самом пак крају X и почетку XI века бугарски цар Самуило предузео је велики поход на запад, који је једнако угрозио и српску кнежевину Дукљу и византијске градове Драчке теме. Према житију Св. Јована Владимира, тадашњег дукљанског и српског кнеза, сачуваном у оквиру тзв. Летописа попа Дукљанина, српски кнез се од освајача склонио

${ }^{53}$ J. Ferluga, Sur la date de la creation du theme de Dyrrachium, Actes du XII ${ }^{\mathrm{e}}$ Congrès International des Études Byzantines II, Belgrade 1964, 83-92; В. Поповић, Албанија y касној Антици, Илири и Албанци, ур. М. Гарашанин, Београд 1988, 201-250.

${ }^{54}$ Constantine Porphyrogenitus De administrando imperio, edd. Gy. Moravcsik, R. J. H. Jenkins, Washington 1967 (CFHB 1), 30.95-97. Б. Новаковић, Дукља у спису De administrando imperio, ЗРВИ 49 (2012) 78-79. и карта на стр. 82, сматра да је Дукља обухватала целокупну територију до реке Дрим, укључујући и Скадар, изузев самих градова Бара и Улциња, али за то гледиште нема чвршћих аргумената.

${ }^{55}$ Notitiae episcopatuum ecclesiae Constantinopolitanae, ed. J. Darrouzès, Paris 1981, 10.607-623. Према ранијој нотицији бр. 7, насталој почетком X века, Драчка митрополија није обухватала поменуте градове, него само Стефанијаку, Хунавију, Кроју и Љеш, Notitiae, 7.643-647. 
на планину Облик, данашњи Тарабош дуж јужне обале Скадарског језера, док је други део Самуилове војске нападао и опседао град Улцињ. Након што га је присилио на предају, Самуило је Владимира послао у заточеништво у своју престоницу Преспу, одакле га је касније, пошто га је оженио својом кћерком Теодором Косаром, вратио да под његовом врховном влашћу управља својом земљом, доделивши му истом приликом на управу чак и Драчку земљу (terram Duracenorum). ${ }^{56}$ Међутим, пошто је према Јовану Скилици Самуило Драч и Драчку земљу доделио свом другом зету Ашоту Тарониту, ${ }^{57}$ то се под Драчком земљом коју је доделио Владимиру највероватније подразумева њен северни део, односно, по свој прилици, само они Дукљи суседни градови између Дрима, Скадарског језера и мора - Бар, Улцињ, Дриваст, Скадар. ${ }^{58}$ Тако су се они по први пут у историји, макар накратко, нашли у оквиру српске поморске земље Дукље, за чију ће историју наредних векова бити нераскидиво везани.

Иако су приморски градови почетком XI века највероватније били под влашћу дукљанског кнеза Јована Владимира, Царство је убрзо након његове смрти повратило власт над тим градовима, који су се поново нашли у оквиру Драчке теме. Услед таквих околности Срби су под вођством Стефана Војислава 1034-1036. поново отпочели борбу за самосталност. Међутим, тај устанак је био неуспешан, али је вођа Срба успео да се ослободи из заточеништва и већ 1039-1040. године ,заузме земљу Срба“ и, што је за нашу тему значајно, приграби ,десет кентенарија злата“ са брода који се услед лошег времена насукао „на илирске обале“. 59 Чињеница да је Стефан Војислав приграбио злато са насуканог византијског брода јасно сведочи да је он успео да заузме илирске обале, што се по свој прилици односи на јужни део Јадранског приморја, који је до тада припадао Драчкој теми, чија се територија у изворима тог времена

${ }^{56}$ Ljetopis popa Dukljanina, prir. V. Mošin, Zagreb 1950, 78-81; J. Ферлуга, Драч и Драчка област пред крај Х и почетком ХІ века, ЗРВИ 8/2 (1964) 119-121.

${ }^{57}$ Ioannis Scylitzae Synopsis historiarum, ed. J. Thurn, Berlin-New York 1973 (CFHB 5), 342-343.

${ }^{58}$ В. Златарски, История на българската държава през средните векове I-2, София 1927, 714; Ј. Ферлуга, Драч и Драчка област, 121; Т. Живковић, Портрети српских владара (IX-XII век), Београд 2000, 67-71. У области између Скадарског језера и Јадранског мора постоји врло јака народна традиција о Св. Јовану Владимиру, С. Новаковић, Први основи словенске књижевности међу балканским Словенима. Легенда о Владимиру и Косари, Београд 1893, 218-237.

59 Scylitzes, 408; J. Ферлуга, Драч и Драчка област, 123-130; П. Коматина, Србија и Дукља у делу Јована Скилиие, ЗРВИ 49 (2012) 159-180. 
често назива Илириком. ${ }^{60}$ Та велика победа Стефана Војислава је веома узнемирила цара Михаила IV, који је одмах послао војску против Срба непосредно из Цариграда. Због неприступачности терена та казнена експедиција је пропала, ${ }^{61}$ те је цар одлучио да архонт Драча, патрикије Михаило, „прикупи стратиотску војску Драча која је била под њиме, као и војске из суседних тема које су биле њему подређене“ и да „заједно са хипостратезима крене на Србе“". ${ }^{62}$ Није невероватно да су управо ти „хипостратези“ били заповедници војника стационираних у градовима у Приморју. Ипак, Стефан Војислав је однео победу којом је осигурао своја освајања, те су се под његовом влашћу поред Србије, Дукље, Травуније и Захумља нашли и Скадар, Бар, Дриваст и Улцињ. ${ }^{63}$ Војислављеви наследници су успели да одрже власт над том територијом. Његов син Михаило је столовао у жупи Прапратни која се налазила између Бара и Улциња, ${ }^{64}$ а унук Бодин у Скадру. ${ }^{65}$ Међутим, Византици се нису лако мирили са чињеницом да су Срби загосподарили не само у загорској Србији, већ и у градовима на дукљанском приморју. Скиличин Настављач нас обавештава како је „народ Словена“ одбацио покорност Ромејима

${ }^{60}$ УП. Nicephori Bryennii Historiarum libri quattuor, ed. P. Gautier, Bruxelles 1975 (CFHB 9), 211-217, 225, 283, који Драч и назива „главним градом ( Илирика“, ibidem, 213; Т. Живковић, Дукљьанско-византијски рат 1072-1075, ИЧ 47 (2000) 51.

${ }^{61}$ Scylitzes, 409.

${ }^{62}$ Scylitzes, 424-425.

${ }^{63}$ Кекавмен, Советы и рассказы. Поучение византийского полководиа XI века, изд. Г. Г. Литаврин, Санкт Петербург 2003, 184, такође доноси вести о упадима Византинаца у Дукљу и јунаштву Стефана Војислава, П. Коматина, Србија и Дукља, 163-164; И. Коматина, Црква и држава у српским земљама од XI до XIII века, Београд 2016, 129.

И у црквеном смислу су епископије приморских градова одступиле од Драчке митрополије Цариградске патријаршије и прикључиле се Дубровачкој архиепископији Римске цркве. Из нотиције бр. 13 која је настала крајем XI века види се да је деловање Драчке митрополије на простору Дукље престало, јер се под њеном јурисдикцијом помињу поред Драча још само четири епископије: Стефанијака, Кроја, Хунавија и Љеш, Notitiae, 13.661-666; И. Коматина, Црква и држава, 132, 137.

${ }^{64}$ Михаило Деволски наводи и још једну његову престоницу, Декатеру (Котор), Ioannes Skylitzes Continuatus, ed. E. Tsolakēs, Thessalonikē 1968, 163.

${ }^{65}$ Raimundi de Aguilers, canonici Podiensis Historia Francorum qui ceperunt Iherusalem, Recueil des Historiens des Croisades, Historiens Occidentaux III, Paris 1866, 236; Orderici Vitalis Ecclesiasticae Historiae libri tredecim III, ed. A. Le Prevost, Parisis 1845, 485-486; И. Коматина, Срби на путу крстама, ИЧ 64 (2015) 64-66. 
на територији Бугарске теме 1072. године, те да су за вођу свог устанка изабрали Константина Бодина. Међутим, Нићифор Вријеније у свом делу Материјал историје осим тих вести доноси и занимљиве податке да су ce „са друге, опет, стране Хрвати и Дукљани“ побунили и „цео Илирик злостављали“. Наиме, када је његов истоимени предак успео да примири устанак на простору Бугарске, цар Михаило Дука је решио да га премести у Драч, главни град Илирика. Разлог томе је, како смо рекли, чињеница да су Срби нападали и узнемиравали градове широм Драчке теме, односно Илирика. Дука Драча Нићифор Вријеније је повео велику војску против „Дукљана и Хрвата“, а до самих борби је дошло вероватно негде на простору између Скадра и Драча. Како су Визнатинци у том сукобу били успешнији уследило је потчињавање свих градова „према Ромејима“, који су, како млађи Нићифор Вријеније наводи, „и раније њима били потчињени“. Након што је узео таоце и сместио војну посаду у сваком граду, дука се вратио у Драч. ${ }^{6}$ Нема сумње да је драчки дука у том походу успешно вратио у оквир Драчке теме важне градове: Скадар, Бар, Улцињ и Дриваст.

Ипак, чини се да Византија није дуго уживала у том тријумфу, тј. да речени градови нису задуго после српско-византијског ратовања остали у оквиру Драчке теме. Наиме, папа Гргур VII позива српског краља Михаила у писму из 1078. да пошаље „Петра барског епископа и дубровачког“ и друге посланике како би се решио спор који је у то време постојао између сплитске и дубровачке цркве. ${ }^{67}$ По свој прилици Бар се убрзо поново нашао под влашћу српског краља, а вероватно и остали приморски градови. Да се српска власт над тим градовима усталила сведочи и спис Алексијада Ане Комнине у ком је њено запажање да река Дрим „протиче границом Далмата (Срба)“, тј. да раздваја српску од византијске области, односно од њене Драчке теме. ${ }^{68}$

Након српског освајања у XI веку, јужнојадрански приморски градови чинили су једну целину са старом српском земљом Дукљом или Зетом. Међутим, и у оквиру ње они су задржали своју посебност, тако да се у периоду од XII до XIV века та земља увек називала „Зета и градови“, односно ,Дукља и Далмација““ 69

${ }^{66}$ Nicephorus Bryennius, 213-215; Т. Живковић, Дукљанско-византијски рат, 38-57. ${ }^{67}$ Gregorii VII registrum II, ed. E. Caspar, MGH Epp. sel. II/2, Berolini 1923, 365; И. Коматина, Црква и држава, 135-139.

${ }^{68}$ Annae Comnenae Alexias, ed. D. R. Reinsch, A. Kambylis, Berolini-Novi Eboraci 2001 (CFHB 40.1), XII, 9.6, p. 383.

${ }^{69}$ У једном которском документу из 1166. помиње се извесни Изанације (Исак?) као византијски „дука Дукље и Далмације“, Codex diplomaticus regni Croatiae, 
Поставља се питање зашто су током XII века јужнојадрански градови у оквиру српске земље Дукље (Зете), некадашњи саставни део византијске Драчке теме, почели да се сматрају делом Далмације? Томе је свакако допринело више фактора. У њима је, као и у градовима Далмације, живело претежно романско становништво. У црквеном погледу су још од XI века припадали Дубровачкој архиепископији. ${ }^{70}$ У оквиру „Дукље и Далмације“, поред јужнојадранских градова налазио се и Котор, који је пре доласка под српску власт заиста припадао византијској Далмацији. Све те околности су могле утицати на окретање јужнојадранских градова ка северу и њихово вишеструко политичко, црквено, економско, а у крајњој линији и идентитетско повезивање са Котором и Дубровником, што је и резултирало њиховим укључивањем у оквир геополитичког појма „Далмације“, односно „Горње Далмације“, како се њен јужни део називао између XII и XIV века. ${ }^{71}$ У сваком случају, већ шездесетих година XIII

Dalmatiae et Slavoniae II, ed. T. Smičiklas, Zagreb 1904, 102. Та синтагма остаје уобичајени део титулатуре српских владара, како Вукана Немањића између 1195. и 1207. тако и краљева после 1217, уп. Ђ. Бубало, Титуле Вукана Немањића и традиија дукљанског краљевства, Ђурђеви Ступови и Будимљанска епархија, ур. Б. Тодић, Беране-Београд 2011, 85-91; И. Коматина, Велико краљевство од прва: Крунисање Стефана Немањића и ,традииија Дукьанског краљевства“, ИЧ 65 (2016) 25-31. У аренгама обеју Хиландарских повеља тај простор се назива „Зетом и градовима“, као и у Житију Св. Симеона од Саве, Вукановом јеванђељу, и каснијим, наративним изворима: Хиландарска оснивачка повеља Светога Симеона и Светога Саве, Ђ. Трифуновић, В. Бјелогрлић, И. Брајовић, Осам векова Студенице, ур. епископ жички Стефан, А. Јевтић, Д. Кашић, Београд 1986, 54; Стефан Првовенчани, 2; Свети Сава, Сабрана дела, прир. Т. Јовановић, Београд 1998, 148; Животи краљева и архиепископа српских, написао архиепископ Данило II, изд. Ђ. Даничић, Загреб 1866, 207, 209, 213. Једино Стефан Немањић у свом Житију посвећеном Св. Симеону описујући његово освајање „Зете и градова“ користи назив „Дукља и Далмација“, Стефан Првовенчани, 38.

${ }^{70}$ И. Коматина, Црква и држава, $132 \mathrm{sq}$.

${ }^{71}$ Први пут је назив „Горња Далмација“ у изворима употребљен 1189. године, када је улцињски епископ Павле признао јурисдикцију дубровачког архиепископа, пошто се уверио да је „дубровачка митрополија била мајка и господарица свим црквама Горње Далмације“, $C D$ II, 235; И. Коматина, Црква и држава, 216-217. Средином XIII века сплитски писац Тома Архиђакон користи назив „Горња Далмација“ за градове Дубровник, Котор, Бар, Улцињ, Свач и Дриваст (еріsсорі superioris Dalmatie, civitates maritimas superioris Dalmatiae), Thomae Archidiaconi Spalatensis Historia Salonitanorum atque Spalatinorum pontificum, edd. D. Karbić, M. Matijević-Sokol, J. Ross Sweeney, Budapest-New York 2006, 64-66, 300-302. Дубровачки статут из 1272. такође говори о „градовима Горње Далмације“ (civitates Dalmatiae Superioris), мислећи на оне приморске градове који су лежали 
века сплитски хроничар Тома Архиђакон описује Далмацију у целини као „приморску област која почиње од Епира, где је Драч и простире се до Кварнерског залива“", 72 што је управо и дефиниција која се јавља у Задарском уговору из 1358. и Торинском уговору из 1381. године. То значи да су се Млечани, одричући се тим уговорима свих својих права и претензија у Далмацији „од средине Кварнера до граница Драча“ одрекли и оних које би се тицале јужнојадранских градова. Њихово преузимање Скадра и Дриваста 1396. године јесте било кршење тих уговора, али су они свој поступак оправдали позивањем на документа која говоре о много ранијем времену, када су ти градови били део византијске Драчке теме.

Ипак, након коначног српског освајања у XI веку, бар један од јужнојадранских градова, Скадар, нашао се, врло кратко, још једном у рукама владара који су господарили Драчком земљом. Било је то 1214. године када је епирски владар Михаило Анђео краткотрајно заузео Скадар. Наиме, Михаило је већ мало пре тог догађаја заузео значајне млетачке поседе, међу њима и Драч. ${ }^{73}$ Након тог успеха, како сведочи Стефан у Житију Св. Симеона, епирски владар је желео да заузме и „велико острво“ које је „близу Диоклитије и далматске земље“, ${ }^{74}$ за које Стефан наводи да је „истинити удео мога светог господина“, његовог оца Немање (Св. Симеона), те да је њему дато „на управљање“, али и да је Михаило заузео Скадар, „који уистину Далмацији припада“. 75 Убрзо након напада и заузимања Скадра Михаилов живот се завршио под сумњивим околностима, а Стефан је задржао речене поседе. ${ }^{76}$ Читава та епизода, осим што показује да је дошло до војне акције епирског деспота, открива, и то врло речито Стефанов чврст став да су то територије које су одувек припадале његовом отачаству. Намеће се питање да ли је управо он тада

јужно од Дубровника, Liber statutorum civitatis Ragusii compositus anno 1272, edd. V. Bogišić, K. Jireček, Zagrabiae 1904, liber III, c. LV, p. 79, liber VIII, c. LXII, p. 205-206.

${ }^{72}$ „Nunc vero Dalmatia est regio maritima, incipiens ab Epyro, ubi est Dirachium et protenditur usque ad sinum Quarnarium“, Thomae Archidiaconi Spalatensis Historia, 2.

${ }^{73}$ D. Nicol, The Despotate of Epiros, Oxford 1957, 38; И. Коматина, Историјска подлога чуда, 126-127.

74 „Велико острво“ је највероватније простор између река Дрима и Бојане, Скадарског језера и Јадранског мора, в. И. Коматина, Историјска подлога чуда, 127, нап. 82; Б. Новаковић, ,, Острва Диоклије “, Ономатолошки прилози 21 (2011) 15-18.

${ }^{75}$ Стефан Првовенчани, 88.

${ }^{76}$ И. Коматина, Историјска подлога чуда, 127. 
и покренуо полемику око тога да ли Скадар и околни градови српског приморја (Дриваст, Дањ, Свач, Улцињ, Бар), као и тзв. Дукљанско острво, припадају Драчу или Далмацији. Стефан иначе на неколико места у свом делу истиче како је та територија његова дедовина, али чини се при опису епизоде са Михаилом, посебно. ${ }^{77}$ Да ли су Млечани 1396. у драчком хартофилакију можда наишли управо на податке о тим претензијама Михаила Анђела и употребили их у своју корист или су ипак у питању могли бити још старији документи из времена византијске владавине до XI века, који су се могли чувати у Драчу? Могуће је и једно и друго. Дакле, документи о најстаријем простирању Драчке теме су могли бити сачувани, што сведочи да је тамошња градска администрација беспрекорно функционисала чак и у условима сталних промена врховне управе над градом којих је у периоду 1204-1392. било скоро двадесет.

То је такође и драгоцено сведочанство на основу кога би се могло закључити да је млетачка управа у Драчу, која је свој међународноправни положај темељила на одредбама Задарског и Торинског уговора о границама Драча, себе сматрала наследницом не само Драчког војводства Анжујаца и драчке области Топија, него и Драчке земље којом је господарио Михаило Анђео у време Стефана Немањића, али и још раније Драчке теме, те да је и у њој проналазила своје историјско упориште. Имајући у виду то, као и чињеницу да назив „Албанија“ током XIII и XIV века најчешће није, осим у техничком смислу „Краљевине Албаније“, обухватао град Драч, већ само његово залеђе у коме су живели Албанци, те да је и Карло Топија у својој титули „кнеза Албаније и господара Драча“" правио јасну разлику између те две политичке целине и да је његов син Ђорђе Топија као владар и Драча и Албаније користио само титулу „господар Драча“, сасвим је разумљиво да ни сами Млечани у првим годинама своје владавине у Драчу и Албанији, између 1392. и 1396, за

\footnotetext{
77 У време Немањиног рођења, дакле око 1113, пише Стефан, „био је велики метеж у овом крају српске земље и Диоклитије и Далмације и Травуније“, Стефан Првовенчани, 18. Такође, Немања је у периоду 1183-1186. „повратио Диоклитију и Далмацију, отачаство и рођење своје, истиниту своју дедовину“, коју је силом држао грчки народ, и градове у њој „сазидане од руку њихових“ - Дањ, Сард, Дриваст, Скадар, Свач, Улцињ, Бар, док је у Котору поставио свој двор, Стефан Првовенчани, 38, 40; И Равић, Писмо барског епископа Гргура сплитском канонику Гвалтерију. Прилог датирању Немањиног напада на градове у Дукљи, CCA 10 (2011) 183-190.
} 
те своје поседе нису користили назив „Албанија“, него „Драч“ ${ }^{78}$ Тек се у августу 1396. године, дакле након ширења млетачке власти и на раније српске градове Скадар и Дриваст, први пут у млетачким актима јавља формулација „Драч, Скадар и остала наша места у Албанији“. ${ }^{79}$ Од тада, и поред тога што се у актима и даље наводе појединачно „Драч, Скадар, Дриваст, Љеш и остала места Албаније“, израз „предели Албаније““ (partes Albaniae) постаје све више уобичајени заједнички назив за све млетачке поседе у јужнојадранском приморју. ${ }^{80}$

\section{Албанија и Зета}

Назив „Албанија“ за српске приморске градове прихватио је, чини се, и сам Ђурађ II Страцимировић Балшић, који се у једном акту издатом у његово име на Корчули маја 1399. јавља са титулом „кнеза Албаније“ (princeps Albaniae) ${ }^{81}$ Исто тако, према Константину Филозофу и његовом Житију деспота Стефана, у јесен 1402. године, на повратку из Ангорске битке и Цариграда, деспот Стефан Лазаревић је приспео „у Арбанасе“,

78 „Civitas nostra Durachii”, ,partes Durachii”, „dominium Durachii”, Acta Albaniae II, 486 sq; $A A V \mathrm{I} / 2$, no. 456 sq.

79 „Durachii et Scutari et aliorum locorum nostrorum Albanie“, Acta Albaniae II, no. 559; $A A V \mathrm{I} / 3$, no. 639; O. J. Schmitt, Venezianische Albanien, 52-53.

${ }^{80}$ Acta Albaniae II, no. 620, 631; AAV I/3, no. 641-642, 644, 831, 924-925, 1033, 1037-1038, 1098, 1101, 1105-1106, 1112, 1114, 1116, 1130, 1136, 1139, 1146, 1150, 1153, 1160-1161, 1165, 1174-1176, 1182, 1186-1188, 1193, 1197-1198, 1214, 1217. На ширење назива „Албанија“ у оквиру млетачке администрације на раније градове српског Поморја свакако је имало утицаја и насељавање албанског становништва у тим градовима, које се управо у то време интензивирало, М. Антоновић, Град и жупа у зетском приморју и северној Албанији у XIV и XV веку Београд 2003, 243-306.

${ }^{81}, \ldots .$. regente... domino Sigismundo, dei gratia Ungariae, Dalmaciae, Croaciae etc. rege inclito..., temporeque magnifici et potentis domini domini Georgii Stracimiri de Balsa, eadem gratia principis Albaniae ac pro ipsa regia maiestate comitis insularum Curzulae et Lesnae..., “ CD XVIII, Zagreb 1990, 436, nо. 307. К. Јиречек, Л. Талоци и М. Шуфлај, Acta Albaniae II, n. 579, изнели су гледиште како је титулу „кнеза Албаније“ Ђурђу II доделио угарски краљ Жигмунд заједно са титулама кнеза Корчуле и Хвара, када је децембра 1396, враћајући се поморским путем у своје краљевство после никопољске катастрофе, боравио у Дубровнику. Истог је мишљења и O. J. Schmitt, Venezianische Albanien, 244, који сматра да је Жигмунд то учинио из протеста против млетачког учвршћивања у северној Албанији. Међутим, из наведеног акта се јасно види да је Ђурађ II био „кнез Албаније“ eadem (dei) gratia, док је pro ipsa regia maiestate био само „кнез острва Корчуле и Хвара“. 
где га је са почастима дочекао његов зет Ђурађ II Балшић, „арбанашки господин““. ${ }^{82}$ Када се тако назив „Албанија“ проширио на приморски део старе српске земље „Дукље и Далмације“, односно „Зете и градова“, 83 он се постепено пренео и на њену унутрашњост. Назив „Албанија“ тако улази у латинску верзију владарске титуле српских деспота као еквивалент српском „Поморју“ („деспот господин Србљем и Поморју Зетском“ - „regni Rasciae et Albaniae despotus“), ${ }^{84}$ а с тим и схватање да се „Албанија“ простире све до Острога. ${ }^{85}$ Прва половина XV века била је испуњена сталним ратовима Балшића и српских деспота после њих са Млечанима у жељи да поврате приморске градове, у којој српски владари, суочени и са непрестаном опасношћу од Османлија, нису имали изгледе на трајнији успех. Млечани су тако својим ранијим поседима у Албанији придодали не само преостале јужнојадранске градове (Улцињ и Бар), него и Котор и Будву, ${ }^{86}$ а успостављањем своје врховне власти над Црнојевићима 1451. године и саму Горњу Зету. ${ }^{87}$

С друге стране, само албанско залеђе Драча, тј. изворна Албанија, углавном није ни припадала „Млетачкој Албанији“. Након што је Константин Балшић, брат од стрица Ђурђа II, крајем 1394. освојио Кроју од Марка Барбадика и Јелене Топије који су њом владали у млетачко име, тим градом и његовом територијом су углавном политички доминирале Османлије, све до Скендербеговог устанка 1443. године. Као нови „господар Албаније“, Скендербег је 1451. године признао врховну власт сицилијанског краља Алфонса V из арагонске династије, враћајући се традицији „Краљевине Албаније“ из анжујских времена. Тек после његове смрти 1468. Млечани су успели да завладају Кројом и остатком праве

${ }^{82}$ Константин Философ и његов живот Стефана Лазаревића деспота српског. По двјема српско-словенским рукописима изновице издао В. Јагић, Гласник СУД 42 (1875) 280.

${ }^{83}$ Свега неку годину раније папа Бонифације IX 1391. истог Ђурђа Страцимировића Балшића назива „господарем и кнезом Зете у Краљевини Рашкој“ (dilecto filio nobili viro Georgio Stratimiro de Balssa domino et principi Czente in regno Rascie), Acta Albaniae II, n. 465-466, а у једном млетачком акту из 1395. његов отац Страцимир (+ 1372) помиње се као „великаш приморске Србије“ (pater suus Strazimirus baro maritimae Sclavoniae), Acta Albaniae II, n. 532.

${ }^{84}$ К. Јиречек, Историја Срба II, Београд 1952², 343-349.

${ }^{85}$ И. Божић, Улога и организација ратничких дружина у Зети XV века, Немирно Поморје, 160 .

${ }^{86}$ ИЦГ II/2, 85-171, 187-232; И. Божић, Албанија и Арбанаси, 67-69; О. J. Schmitt, Venezianische Albanien, 253-293.

${ }^{87}$ ИЦГ II/2, 277-347. 
Албаније, али су је изгубили већ 1478, заједно са Скадром, Дривастом, Дањом и Љешом, које су предали Османлијама Скадарским миром 1479. године ${ }^{88}$ Скадарски санџак, који су Османлије основале након освајања Скадра, Дриваста, Дања и Љеша, имао је своје чврсто геополитичко утемељење у „Млетачкој Албанији““ ${ }^{89}$ С друге стране, османским освајањем Драча 1501. и затим Улциња и Бара 1571. године, сама „Млетачка Албанија“ била је сведена на подручје градова Будве и Котора, ${ }^{90}$ далеко изван оквира древне византијске Драчке теме, у којој је имала своје историјско упориште.

${ }^{88}$ И. Божић, Албанија и Арбанаси, 72-84.

${ }^{89}$ ИЦГ II/2, 308-321; О. J. Schmitt, Venezianische Albanien, 595-633.

${ }^{90}$ ИЦГ II/2, 150; И. Божић, Албанија и Арбанаси, 84; O. J. Schmitt, Venezianische Albanien, 629-631. 
Настанак „Млетачке Албаније“ и успомена на византијску власт у српском поморју

\section{ЛИСТА РЕФЕРЕНЦИ - LIST OF REFERENCES}

\section{Извори - Primary Sources}

Acta Albaniae Veneta saeculorum XIV et XV, ed. J. Valentini, I/1, Panormi 1967; I/2, Mediolani 1968. Acta et diplomata res Albaniae mediae aetatis illustrantia I-II, edd. L. Thalloczy, K. Jireček, E. Sufflay, Vindobonae 1913-1918.

Annae Comnenae Alexias, edd. D. R. Reinsch, A. Kambylis, Berolini-Novi Eboraci 2001 (CFHB 40.1)

Anonymi descriptio Europae Orientalis, прир. Т. Живковић, В. Петровић, А. Узелац, Београд 2013. [Anonymi descriptio Europae Orientalis, prir. T. Živković, V. Petrović, A. Uzelac, Beograd 2013]

Codex diplomaticus regni Croatiae, Dalmatiae et Slavoniae, ed. T. Smičiklas, II, Zagreb 1904; XVIII, Zagreb 1990.

Constantine Porphyrogenitus De administrando imperio, edd. Gy. Moravcsik, R. J. H. Jenkins, Washington 1967 (CFHB 1)

Georgii Acropolitae Opera I, edd. A. Heisenberg, P. Wirth, Stutgardiae 1978.

Gregorii VII registrum II, ed. E. Caspar, MGH Epp. sel. II/2, Berolini 1923.

Hopf C., Chroniques Gréco-romanes, Berlin 1873.

Ioannes Skylitzes Continuatus, ed. E. Tsolakēs, Thessalonikē 1968.

Ioannis Scylitzae Synopsis historiarum, ed. J. Thurn, Berlin-New York 1973 (CFHB 5)

Itinerarium Symon Semeonis ab Hyberniam ad Terram Sanctam, ed. M. Esposito, Dublin 1960.

Константин Философ и његов живот Стефана Лазаревића деспота српског. По двјема српско-словенским рукописима изновиче издао В. Јагић, Гласник СУД 42 (1875) 223328. [ Konstantin Filosof i njegov život Stefana Lazarevića despota srpskog. Po dvjema srpsko-slovenskim rukopisima iznovice izdao V. Jagić, Glasnik SUD 42 (1875) 223-328]

Liber statutorum civitatis Ragusii compositus anno 1272, edd. V. Bogišić, K. Jireček, Zagrabiae 1904. Ljetopis popa Dukljanina, prir. V. Mošin, Zagreb 1950.

Ljubić S., Listine o odnošajih izmedju Južnoga Slavenstva i Mletačke republike III, Zagreb 1872; IV, Zagreb 1874.

Nicephori Bryennii Historiarum libri quattuor, ed. P. Gautier, Bruxelles 1975 (CFHB 9)

Nicephori Gregorae Byzantina Historia I, ed. L. Schopen, Bonnae 1829 (CSHB)

Notitiae episcopatuum ecclesiae Constantinopolitanae, ed. J. Darrouzès, Paris 1981.

Orderici Vitalis Ecclesiasticae Historiae libri tredecim, III, ed. A. Le Prevost, Parisiis 1845.

Raimundi de Aguilers, canonici Podiensis Historia Francorum qui ceperunt Iherusalem, Recueil des Historiens des Croisades, Historiens Occidentaux, III, Paris 1866.

Рудић С., Повеља дуке драчког Балше II Дубровчанима, CСА 11 (2012) 101-106. [Rudić S., Povelja duke dračkog Balše II Dubrovčanima, SSA 11 (2102) 101-106]

Thallóczy L., Jireček C., Zwei Urkunden aus Nordalbanien, Archiv für slavische Philologie 21 (1899) 78-99.

Thomae Archidiaconi Spalatensis Historia Salonitanorum atque Spalatinorum pontificum, edd. D. Karbić, M. Matijević-Sokol, J. Ross Sweeney, Budapest-New York 2006.

Животи краљева и архиепископа српских, написао архиепископ Данило II, изд. Ђ. Даничић, Загреб 1866. [Životi kraljeva i arhiepiskopa srpskih, napisao arhiepiskop Danilo II, izd Đ. Daničić, Zagreb 1866] 
Кекавмен, Советы и рассказы. Поучение византийского полководйа ХІ века, изд. Г. Г. Литаврин, Санкт Петербург 2003. [Kekavmen, Sovety i raskazy. Poučenie vizantijskogo polkovodca XI veka, izd. G. G. Litavrin, Sankt-Peterburg 2003]

Свети Сава, Сабрана дела, прир. Т. Јовановић, Београд 1998. [Sveti Sava, Sabrana dela, prir. T. Jovanović, Beograd 1998]

Стефан Првовенчани, Сабрана дела, изд. Љ. Јухас-Георгиевска, Т. Јовановић, Беогард 1999. [Stefan Prvovenčani, Sabrana dela, izd. Lj. Juhas-Georgievksa, T. Jovanović, Beograd 1999]

Томовић Г., Морфологија ћириличких натписа на Балкану, Београд 1974. [Tomović G., Morfologija ćiriličkih natpisa na Balkanu, Beograd 1974]

Хиландарска оснивачка повеља Светога Симеона и Светога Саве, Ђ. Трифуновић, В. Бјелогрлић, И. Брајовић, Осам векова Студенице, ур. епископ жички Стефан, А. Јевтић, Д. Кашић, Београд 1986, 49-60. [Hilandarska osnivačka povelja Svetoga Simeona i Svetoga Save, Đ. Trifunović, V. Bjelogrlić, I. Brajović, Osam vekova Studenice, ur. episkop žički Stefan, A. Jevtić, D. Kašić, Beograd 1986, 46-60]

\section{Литература - Secondary Works}

Ducellier A., La façade maritime de l'Albanie au moyen age. Durazzo et Valona du XIe au XVe siècle, Thessaloniki 1981.

Ferluga J., Sur la date de la creation du theme de Dyrrachium, Actes du XII Congrès International des Études Byzantines II, Belgrade 1964, 83-92.

Nicol D., The Despotate of Epiros, Oxford 1957.

Schmitt O. J., Das venezianische Albanien (1392-1479), München 2001.

Антоновић М., Град и жупа у зетском приморју и северној Албанији у XIV и XV веку Београд 2003. [Antonović M., Grad $i$ župa u zetskom primorju i severnoj Albaniji u XIV $i$ $X V$ veku, Beograd 2003]

Божић И., Dominus rex Constantinus, Немирно Поморје XV века, Београд 1979, 195-205. [Božić I., Dominus rex Constantinus, Nemirno Pomorje XV veka, Beograd 1979, 195-205]

Божић И., Албанија и Арбанаси у XIII, XIV и XV веку, Глас САНУ 338, Одељење историјских наука, књ. 3 (1983) 11-116. [Božić, I., Albanija i Arbanasi u XIII, XIV i XV veku, Glas SANU 338, Odeljenje istorijskih nauka, knj. 3 (1983) 11-116]

Божић И., Улога и организаиија ратничких дружина у Зети XV века, Немирно Поморје, 156-173. [Božić, I., Uloga i organizacija ratničkih družina u Zeti XV veka, Nemirno Pomorje, 156-173]

Бубало Ђ., Титуле Вукана Немањића и традииија дукљанског краљевства, Ђурђеви Ступови и Будимљанска епархија, ур. Б. Тодић, Беране - Београд 2011, 79-94. [Bubalo Đ., Titule Vukana Nemanjića i tradicija dukljanskog kraljevstva, Đurđevi Stupovi i Budimljanska eparhija, ur. B. Todić, Berane - Beograd 2011, 79-94]

Живковић Т., Дукљанско-византијски рат 1072-1075, ИЧ 47 (2000) 35-57. [Živković Т., Dukljansko-vizantijski rat 1072-1075, IČ 47 (2000) 35-57]

Живковић Т., Портрети српских владара (IX-XII век), Београд 2000. [Živković T.,Portreti srpskih vladara (IX-XII vek), Beograd 2000]

Живојиновић Д., Хоризма бугарског ичара Јована Асена II Дубровнику, Иницијал 1 (2013) 229-239. [Živojinović D., Horizma bugarskog cara Jovana Asena II Dubrovniku, Inicijal 1 (2013) 229-239]

Златарски В., История на българската държава през средните векове I-2, София 1927. [Zlatarski V., Istorija na b'lgarskata država prez srednite vekove I-2, Sofija 1927]

Историја Црне Горе II/2, Титоград 1970. [Istorija Crne Gore II/2, Titograd 1970] 
Настанак „,Млетачке Албаније“ и успомена на византијску власт у српском поморју

Јиречек К., Историја Срба II, Београд 1952² [ Jireček K., Istorija Srba II, Beograd 1952²] Коматина И., Велико краљевство од прва: Крунисање Стефана Немањића и „традииија Дукљанског краљевства“, ИЧ 65 (2016) 13-32. [Komatina I., Veliko kraljevstvo od prva: Krunisanje Stefana Nemanjića i ,, tradicija Dukljanskog kraljevstva“, IČ 65 (2016) 13-32]

Коматина И., Историјска подлога чуда Св. Симеона у Житију Симеоновом од Стефана Првовенчаног, ЗРВИ 51 (2014) 112-134. [Komatina I., Istorijska podloga čuda Sv. Simeona u Žitiju Simeonovom od Stefana Prvovenčanog, ZRVI 51 (2014) 112-134]

Коматина И., Срби на путу крсташа, ИЧ 64 (2015) 55-83. [Komatina I., Srbi na putu krstaša, IČ 64 (2015) 55-83]

Коматина И., Црква и држава у српским земљама од XI до XIII века, Београд 2016. [Komatina I., Crkva i država u srpskim zemljama od XI do XIII veka, Beograd 2016]

Коматина П., „А од Арбанаса Пилот “: Почеци политичке историје Албанаца, Стефан Немања - Преподобни Симеон Мироточиви, Зборник радова, Београд-Беране 2016, 135-143. [Komatina P., ,A od Arbanasa Pilot": Počeci političke istorije Albanaca, Stefan Nemanja - Prepodobni Simeon Mirotočivi, Zbornik radova, Beograd-Berane 2016, 135-143]

Коматина П., Област Вагенитија и епископија Св. Климента, ЗРВИ 53 (2016) 83-100. [Komatina P., Oblast Vagenitija i episkopija Sv. Klimenta, ZRVI 53 (2016) 83-100]

Коматина П., Србија и Дукља у делу Јована Скиличе, ЗРВИ 49 (2012) 159-186. [Komatina P., Srbija i Duklja u delu Jovana Skilice, ZRVI 49 (2012) 159-186]

Новаковић Б., , Острва Диоклије“, Ономатолошки прилози 21 (2011) 15-18 [Novaković B., ,,Ostrva Dioklije“, Onomatološki prilozi 21 (2011) 15-18].

Новаковић Б., Дукља у спису De administrando imperio, ЗРВИ 49 (2012) 75-86. [Novaković B., Duklja u spisu De administrando imperio, ZRVI 49 (2012) 75-86]

Новаковић С., Први основи словенске књижевности међу балканским Словенима. Легенда o Владимиру и Косари, Београд 1893. [Novaković S., Prvi osnovi slovenske književnosti među balkanskim Slovenima. Legenda o Vladimiru i Kosari, Beograd 1893]

Острогорски Г., Историја Византије, Београд 1959. [Ostogorski G., Istorija Vizantije, Beo$\operatorname{grad} 1959]$

Поповић В., Албанија у касној Антици, Илири и Албанци, ур. М. Гарашанин, Београд 1988, 201-250. [Popović V., Albanija u kasnoj Antici, Iliri i Albanci, ur. M. Garašanin, Beograd 1988, 201-250]

Равић И., Писмо барског епископа Гргура сплитском канонику Гвалтерију. Прилог датирању Немањиног напада на градове у Дукљи, CCA 10 (2011) 183-190. [Ravić I., Pismo barskog episkopa Grgura splitskom kanoniku Gvalteriju. Prilog datiranju Nemanjinog napada na gradove u Duklji, SSA 10 (2011) 183-190]

Ферлуга Ј., Драч и Драчка област пред крај Х и почетком ХІ века, ЗРВИ 8/2 (1964) 117-132. [Ferluga J., Drač i Dračka oblast pred kraj X i početkom XI veka, ZRVI 8/2(1964) $117-132]$ 


\title{
Ivana Komatina \\ Predrag Komatina
}

\section{THE ESTABLISHMENT OF "VENETIAN ALBANIA" AND THE MEMORY OF BYZANTINE RULE IN THE SERBIAN LITTORAL}

\begin{abstract}
Summary
The paper deals with the facts that led to the creation of "Venetian Albania". Namely, "Venetian Albania" (Albania Veneta) was a historical and geographical entity that emerged after the Venetian takeover of Durazzo from its Albanian master George Topia in 1392, and survived until the peace of Campoformio and the annexation of Venice and the remaining Venetian lands in the Adriatic to Austria in 1797. Although its origin was related to the Venetian occupation of Durazzo, its territory lay primarily, and after the fall of Durazzo, under the Ottomans in 1501, in the area of the medieval Serbian Littoral, from Cattaro to Scutari, which before the spread of "Venetian Albania" was never considered to be "Albania".

However, it is first necessary to explain the geographical, historical and political relationship between original Albania and newly established "Venetian Albania“. Albania, that is, the Arbanum region - a wider area around the town of Kruje, was initially part of the theme of Durazzo of the Byzantine Empire. After the fall of Constantinople into the hands of Crusaders in 1204, Durazzo fell into the hands of the Venetians, but in the region of Arbanum, we encounter the first testimonies of the Principatus Arbanensis ("Principality of Arbanum") as a political entity. In the following period, Arbanum and Durazzo changed supreme authority several times, firstly Epirote, then Bulgarian, and at the end, the struggle for the control of these territories was fought between the Despotate of Epirus and the Empire of Nicaea. Sicilian King Manfred of Hoenstaufen also participated in these events. After Manfred's death, Charles of Anjou became a pretender to Manfred's inheritance. In order to achieve his goal, in Viterbo in 1267 he made an alliance with Latin emperor Baldwin who acknowledged his rights over Manfred's inheritance in Epirus, as well as in the "kingdom of Albania" (regnum Albaniae), which was the first mention of that term. Based on these provisions, by 1272 Charles had already under his rule Durazzo and Albania. He appointed his captain for the Kingdom of Albania, to whom he subsequently entrusted the administration of Durazzo, which was not considered part of the Kingdom of Albania. The Kingdom of
\end{abstract}


Albania temporarily disappeared in 1284. After the change of the Byzantine and Serbian authorities over Durazzo and the Albanian hinterland, the Angevine pretensions were revived with Philip of Taranto and in 1304 he issued a series of privileges to the Durazzins and "the estates of the Kingdom of Albania". However, although the city of Durazzo was treated as a separate entity, this time during the Angevine rule, it completely belonged to the restored Kingdom of Albania. During the time of Philip's successors, Durazzo was constituted as a separate Duchy of Durazzo and was again separated from the rest of the "Kingdom of Albania". The rule of the Duke of Durazzo over the "Kingdom of Albania" was still unstable and dependent upon the loyalty of Albanian nobles. During the 1340s, they recognised Serbian authority, after which the Angevine "Kingdom of Albania" ceased to exist, but the Duchy of Durazzo held up until 1368, when it was won over by Charles Topia, an Albanian local nobleman. Once again, Durazzo and its Albanian hinterland were united under the rule of the same lord.

As early as 1362 , the Durazzins came into close contact with the Venetians, and four years later, Charles Topia received the privileges of Venetian citizenship. His son George Topia also had close cooperation with the Venetians.

However, after George's death in 1392, the city and its Albanian hinterland came in possession of the Venetians, and that is how "Venetian Albania" came into existence, although that term was still unknown. So the only link between original Albania and "Venetian Albania", except for the name, was the city of Durazzo. "Venetian Albania" did not spread to the east, to the core of Albania - former Arbanum; on the contrary, it was soon extended to the north, thanks to the lord of Zeta, George II Stratimirović Balšić. Namely, he offered the cities of Scutari and Drivasto to the Venetians. However, the Venetians were not allowed to accept them at once, as they would violate the peace provisions with the Hungarians of 1358 and 1381, which meant that the Hungarian authority would extend through all of Dalmatia, from "Quarnaro to the borders of Durazzo". Therefore, Scutari and Drivasto were certainly located within that area. Nevertheless, skilled Venetians, wanting to extend the boundaries of "Venetian Albania" to the north, ordered their captain of Durazzo to find in the old acts whether those cities belonged to Dalmatia or to the "borders of Durazzo". The captain of Durazzo obviously found some ancient writings, even from the period of the Byzantine authority about the spread of the theme of Durazzo over those cities in the period from the $9^{\text {th }}$ to the $11^{\text {th }}$ centuries (which is evidenced by the works of Constantine VII Porphyrogenitus, John Scylitzes, Scylitzes Continuatus, Nicephorus Bryennius, Anne Comnene). After the Serbian conquest of these towns in the middle of the $11^{\text {th }}$ century, they made a whole with the old Serbian land of Dioclea (Zeta), but they retained a specific 
status, so we often encounter the phrases "Zeta and the Cities" or "Dioclea and Dalmatia", where under Dalmatia the area of Upper Dalmatia was meant. In the $13^{\text {th }}$ century Thomas the Archdeacon defined the entirety of Dalmatia as an area starting from Epirus and Durazzo and extending to the Quarnaro Bay, just like in the treaties of 1358 and 1381 . The Venetians thus violated these provisions, but they justified their own actions by calling upon the former affiliation of these cities to the Byzantine theme of Durazzo. A similar dispute over the issue of whom these cities, Scutari in particular, belonged to - Dalmatia or Durazzo, was initiated by Serbian grand župan Stefan Nemanjić in 1214. The Venetians perhaps used the evidence pertaining to that dispute, in addition to finding older documents from the time of Byzantine rule.

It was only then that after the spread of the Venetian power over the southern Adriatic cities of Scutari and Drivasto that the name of "Albania" was first used. Since then, it became a more common name for the Venetian territories in the South Adriatic, and gradually spread to the north, eventually encompassing all of Zeta. The Turkish founding of the Sanjak of Scutari in 1479 had a strong geopolitical foundation in "Venetian Albania", and as it included Montenegro and Brda, they were considered a part of Albania up until the $19^{\text {th }}$ century. On the other hand, "Venetian Albania" after the Turkish conquest of Durazzo in 1501 was reduced only to the areas of the cities of Budva and Cattaro, far beyond the borders of the theme of Durazzo, its original core.

Keywords: "Venetian Albania", Albania, Durazzo, Zeta, Upper Dalmatia, Serbian Littoral.

Чланак примљен: 31. 01. 2018.

Чланак коначно прихваћен за објављивање: 15. 05. 2018. 